\title{
HPCA Gene
}

National Cancer Institute

\section{Source}

National Cancer Institute. HPCA Gene. NCI Thesaurus. Code C24476.

This gene plays a role in signal transduction and is involved in the regulation of cytosolic calcium ion concentration. 